\title{
AS THE AGRICULTURE, FORESTRY AND FISHERIES SECTOR STILL AS A POTENTIAL IN THE PROSPERITY OF INDONESIAN SOCIETY?
}

\author{
Nugrahini Susantinah Wisnujati*, Markus Patiung \\ Magister Agribussines, Agriculture Faculty/ Wijaya Kusuma Surabaya University, Indonesia \\ *corresponding author: nugrahiniwisnujati@yahoo.co.id
}

\begin{abstract}
All countries on the planet possibly be overseen ideally with the goal that their kin are prosperous. The Indonesian country has the potential for normal assets (ranger service, ranches, domesticated animals, fisheries and food crops) which in the Gross Provincial Homegrown Item (PDRB) are contracted as horticulture, ranger service and fisheries. The capability of the Indonesian country has endured a ton of harm and capacity changes. The exploration goals are (1) to investigate the horticultural, ranger service and fisheries parts as manageable areas or not, which add to the Gross Provincial Homegrown Item, (2) to dissect whether the farming, ranger service and fisheries divisions can succeed the Indonesian public. The explanatory strategies utilized are Area Remainder (LQ), Dynamic Area Remainder (DLQ) and Klassen Typology. The exploration results show that the horticultural, ranger service and fisheries divisions are essential/potential segments today and later on, although despite the fact their development is moderate and won't be supplanted by different segments until the apocalypse because of God's effortlessness. Just by dealing with its latent capacity, in particular horticulture, ranger service and fisheries, the Indonesian country can thrive its kin, with a note that it is important to join agribusiness and innovation, for example, GIS innovation, nano innovation that utilizes crude materials from farming, ranger service and fisheries.
\end{abstract}

Keywords: agriculture, forestry, fisheries, development, welfare.

http://dx.doi.org/10.21776/ub.agrise.2020.020.4.7

Received 14 September 2020

Accepted 20 October 2020

Available online 30 October 2020

\section{INTRODUCTION}

All countries on the planet, have the potential as a blessing from God. What's more, this potential must be overseen and grown appropriately by the administration so the individuals are prosperous and prosperous (Huda, Miftakhul; Santoso 2014); (Patiung 2018). In Macedonia Farming is one of the most encouraging segments in the Macedonian economy, considering the normal portion of horticulture in Gross domestic product is $10 \%$ and represents $17.87 \%$ of all out business (Ciglovska 2018), in Russia the nation's potential shows a progress to financial development, specifically underscoring the utilization of present day innovation (Babaev, Nikolaeva, and Babaev 2019), then again, Sziemai's examination found that few nations on the planet experienced development from the assembling area, during the nineteenth century onwards, the world economy had been separated into mechanical economies and rural economy, yet the profitability of assembling is higher than the agrarian segment, fabricating has a higher efficiency development rate than different divisions (Szirmai 2012). In ASEAN nations Horticulture is a significant division, in Indonesia the biggest agrarian area creates GDP after Industry, to be specific agribusiness contributing $13.41 \%$, Industry $21.31 \%$, exchange 13.37 , mining $11.05 \%$ and others 40.85 . \% (Nugrahini et al. 2019), Indonesia has the capability of Common Assets (SDA, for example, Ranger service, Estate, Creature Farming, Fisheries and Food Plants, which is the reason Indonesia is known as an agrarian/ horticultural/agtribusiness nation. Indeed, it is trusted that with its latent capacity, the Indonesian country can get one of the world's food suppliers

At the point when a nation oversees past its latent capacity, that is the place the nation falls into destitution. Since dealing with a nation past its potential will require significant expenses, since it doesn't have crude materials and talented work force, so the subsequent item is hard to contend in the global 
market or with different nations. On the off chance that a nation doesn't design well, it will fizzle, This can be seen from the consequences of exploration which show that the Philippines, Thailand, Malaysia, Indonesia, Ecuador and Peru have encountered huge antagonistic effects on the economy, food industry and family units. Vietnam is encountering monetary decrease because of oversaw marine fish assets, in such a case that Vietnam's fish potential isn't overseen appropriately there will be a shortage of fish in the worldwide market which will jeopardize the worldwide exchange wild catch and hydroponics, just as worldwide food security(Nong 2019).

Specialists/specialists express that the most suitable approach to build up the public economy of a nation so its kin are prosperous is to create financial exercises on which the monetary existence of a large portion of its kin is based. Indonesia (60-70\%) populace lives in the horticultural division. Hence the horticultural/agribusiness part should be the benchmark/spine of the public economy. Consequently, the industrialization methodology that must be created is the farming business technique as agribusiness advancement.

The difficult that happens in Indonesia is that the likely controlled by the Indonesian public isn't overseen ideally, even the vast majority of the potential is harmed because of the absence of worry of the populace and the legislature. One model is that Indonesia's backwoods have been harmed and have never been reforested. Such a large number of beneficial terrains have been changed over into nonrural land (right around 1 million ha/year). The administration's consideration regarding agribusiness is low, it is demonstrated that farming isn't the primary decision being developed, so it is hard to create with regards to the government assistance of its kin, left be to turn into a world food supplier. Consequently, this exploration attempts to examine whether the horticultural, ranger service and fisheries segments as one of the monetary divisions that can add to the Gross Local Homegrown Item (GRDP) are supportable or not. With the goal that it can give contribution to neighborhood governments in making arrangements to deal with this part as a possible area for the government assistance of the Indonesian public.

\section{RESEARCH METHODS}

The examination destinations are (1) to investigate the agribusiness, ranger service and fisheries divisions as practical parts or not, which add to Net Local Homegrown Item, (2) to break down whether the horticulture, ranger service and fisheries segments can flourish the Indonesian public.

This examination was led in Ngawi Regime, East Java Area, Indonesia, with the thought that Ngawi Rule, East Java Territory, Indonesia is a locale with agrarian potential. The information utilized in this investigation are optional information, to be specific the Gross Territorial Homegrown Result of Ngawi Regime, East Java Region, Indonesia and the Gross Local Homegrown Result of East Java Region throughout the previous five years.

The explanatory strategies utilized are Area Remainder (LQ), Dynamic Area Remainder (DLQ) and Klassen Typology. The Area Remainder (LQ) investigation strategy is utilized to decide if the agrarian, ranger service and fisheries areas are fundamental/potential or non-premise/non-likely divisions. Then, the Dynamic Area Remainder (DLQ) examination technique is utilized to decide the rural, ranger service and fisheries areas in Ngawi Rule are becoming quicker or more slow than similar segments in the extent of GRDP of East Java Territory. The correlation of LQ and DLQ results can decide if the farming, ranger service and fisheries sertor is remembered for the main, imminent, backbone or slacking segments. Typology arrangement technique investigation is utilized to decide if the horticultural, ranger service and fisheries segments are quickly developing and quickly developing areas, quickly developing segments, progressed and moderate developing divisions, or generally slacking parts.

Then, the LQ count recipe utilized in this investigation is (Budiharsono 2001)

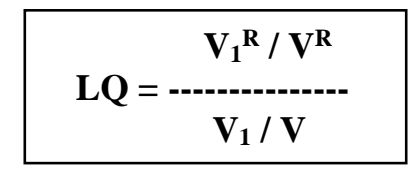

Where:

$\mathrm{V}_{1}{ }^{\mathrm{R}}$ : The value of the agricultural, forestry and fisheries sectors in regency GRDP Ngawi, East Java Province, Indonesia

$\mathrm{V}^{\mathrm{R}}$ : The value of all sectors in the GRDP of Ngawi Regency, East Java Province, Indonesia

V1: The value of the agriculture, forestry and fisheries sectors in the GRDP of Java Province East

$\mathrm{V}$ : The value of all sectors in the GRDP of East Java Province

Based on the location quotient (LQ) analysis, if the value of LQ> 1 then the sector becomes the basis / potential, meaning that the resulting agricultural, forestry and fishery production can not only meet domestic needs but can also be exported abroad. The higher the LQ value than one, the higher the comparative advantage (Cahyono, S Andy and Wijaya 2014). Conversely, if the value of LQ $<1$, then the agricultural, forestry and fisheries sectors are classified as non-basis, have no advantages / nonpotential, the production of these sectors cannot fulfill their own needs so it needs supplies or imports from outside. If the value of $\mathrm{LQ}=1$, the sector is classified as having no advantages, the production of that sector 
is only able to meet domestic needs and cannot be exported.

Changes in the domestic economy over a certain period of time can be tested through Dynamic Location Quotient (DLQ) so that sectoral changes can be identified. DLQ is a modified form of LQ by accommodating the amount of GRDP from the sector production value from time to time. The ups and downs of the DLQ can be seen for certain sectors at different time dimensions with the following formulation (Nazipati 2007):

$$
\mathrm{DLQ}_{\mathrm{ij}}=\frac{\left(1+\mathrm{g}_{\mathrm{ij}}\right) /\left(1+\mathrm{g}_{\mathrm{j}}\right)}{(1+\mathrm{Gi}) /(1+\mathrm{G})}
$$

Where:

DLQij: An index of the potential of the agricultural, forestry and fisheries sectors on GRDP Ngawi District, East Java Province, Indonesia;

gij: The rate of value added growth in the agricultural, forestry and sectors fisheries on GRDP of Ngawi Regency, East Java Province, Indonesia

gj: The average GRDP growth rate of Ngawi Regency, Java Province Eastern Indonesia

Gi: The rate of value added growth in the agricultural, forestry and sectors fisheries in East Java Province GRDP

G: The average GRDP growth of East Java Province

If the DLQ value is more than 1, then the potential development of the agricultural, forestry and fisheries sectors in Ngawi Regency, East Java, Indonesia is faster than the same sector within the scope of Provincial GRDP. Conversely, if the DLQ $<1$, then the potential development of the agricultural, forestry and fisheries sectors in Ngawi Regency, East Java, Indonesia is lower than the GRDP as a whole in the Province.

The comparison between LQ and DLQ values can be used as a criterion in determining whether the agricultural, forestry and fisheries sectors are classified as superior, prospective, mainstay, or underdeveloped sectors. The criteria are as follows (Suyatno 2007):

a. If the value of LQ and DLQ> 1, the leading sector means that the agriculture, forestry and fisheries sectors will remain the basis for both present and future.

b. If the value of LQ> 1 and DLQ $<1$, the sector is prospective, meaning that the agricultural, forestry and fisheries sectors will shift from basic to non-basic sectors in the future. c. If the value of LQ $<1$ and DLQ $>1$ is the mainstay sector, it means that the agriculture, forestry and fisheries sector will shift from the non-base sector to the basic sector in the future.

d. If the value of LQ and DLQ $<1$, the serktor is left behind, it means that the agriculture, forestry and fisheries sectors will continue to be non-bases, both now and in the future.

\section{Formula: Klassen Typology}

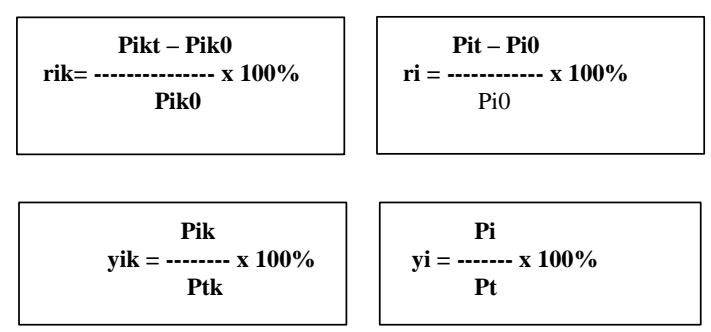

Information

rik $=$ The rate of growth in the production value of the agricultural, forestry and sectors fisheries in Ngawi Regency GRDP

$\mathrm{ri}=$ The rate of growth in the production value of the agricultural, forestry and sectors fisheries in East Java Province GRDP

yik $=$ The contribution of the agriculture, forestry and fisheries sectors to the total value production at GRDP of Ngawi Regency

$\mathrm{yi}=$ The contribution of the agriculture, forestry and fisheries sectors to the total value production at GRDP of East Java Province

Pikt $=$ Production value of the agricultural, forestry and fisheries sectors in GRDP East Java Province year $\mathrm{t}$

Piko $=$ The production value of the agricultural, forestry and fisheries sectors in GRDP Ngawi Regency early in the year

Pit $=$ The production value of the agricultural, forestry and fisheries sectors in GRDP East Java Province year t

Pio $=$ Production value of the agricultural, forestry and fisheries sectors in GRDP East Java Province early this year

Pik $=$ Production value of the agricultural, forestry and fisheries sectors in GRDPNgawi Regency

Ptk $=$ Total production value in Ngawi Regency GRDP

$\mathrm{Pi}=$ The production value of the agricultural, forestry and fisheries sectors in GRDP East Java Province

$\mathrm{Pt}=$ Total production value in East Java Province GRDP

Table 1. Typology of Sector Growth according to Klasse 
Information

rik $=$ The rate of growth in the production value of the agricultural, forestry and sectors fisheries at GRDP of Ngawi Regency

$\mathrm{ri}=\quad$ The rate of growth in the production value of the agricultural, forestry and sectors fisheries in East Java Province GRDP

yik $=$ The contribution of the agriculture, forestry and fisheries sectors to the total value PDRB production of Ngawi Regency

yi $=$ The contribution of the agriculture, forestry and fisheries sectors to the total value PDRB production of East Java Province

\section{RESULTS AND DISCUSSION}

Indonesia is a country that has the potential of abundant natural resources such as forestry, plantations, livestock and fisheries as well as food crops as a gift from God. And that is why Indonesia is called an agricultural / agricultural country in general or what is known today as agribusiness. The Indonesian state must maximize management in agriculture in general or agribusiness to improve the national economy so that the welfare of its people can be prospered. On the one hand, Indonesia as an agricultural country is expected to provide world food.

Table 2. Location Quotient (LQ), Dynamic Location Quotient (DLQ) Analysis and Klassen Typology

\begin{tabular}{|c|c|c|c|}
\hline Sector & $\begin{array}{c}\text { Method of } \\
\text { Analysis }\end{array}$ & Result & criteria \\
\hline \multirow{9}{*}{$\begin{array}{l}\text { Agricultur } \\
\text { e, Forestry } \\
\text { and } \\
\text { Animal } \\
\text { Husbandry }\end{array}$} & LQ & 2,92 & $\begin{array}{l}\text { Basic/ } \\
\text { Potential }\end{array}$ \\
\hline & DLQ & 15,34 & Surplus \\
\hline & LQ \& DLQ & $\mathrm{LQ}>1$ & Superior \\
\hline & Comparation & $\begin{array}{c}\text { DLQ }> \\
1\end{array}$ & \\
\hline & $\begin{array}{c}\text { Klasen } \\
\text { Typology }\end{array}$ & $\begin{array}{c}\text { rik }<\text { ri } \\
\& \text { yik }> \\
\text { yi }\end{array}$ & \multirow{5}{*}{$\begin{array}{l}\text { Advanced } \\
\text { and slow } \\
\text { growing } \\
\text { sector }\end{array}$} \\
\hline & $\mathrm{r}_{\mathrm{ik}}$ & 0,02 & \\
\hline & $\mathrm{r}_{\mathrm{i}}$ & 2,77 & \\
\hline & $\mathrm{y}_{\mathrm{ik}}$ & 0,34 & \\
\hline & $\overline{y_{i}}$ & 0,13 & \\
\hline
\end{tabular}

Source: Data Analysis 2020

From the consequences of the investigation utilizing the Area Remainder (LQ) technique, the outcome is that the LQ esteem is 2.92> 1, implying that the horticultural, ranger service and domesticated animals areas as one of the divisions that add to the Buruto Local Homegrown Item (PDRB) of Ngawi Regime are base part or expected segment. Along these lines, the Administration of Indonesia should truly oversee regular assets so as to thrive its kin. Then

\begin{tabular}{|c|l|l|}
\hline $\begin{array}{c}\text { contribution } \\
\text { growth rate }\end{array}$ & \multicolumn{1}{|c|}{ yik > yi } & \multicolumn{1}{|c|}{ yik < yi } \\
\hline rik > ri & $\begin{array}{l}\text { The sector is } \\
\text { developed and } \\
\text { growing fast }\end{array}$ & $\begin{array}{l}\text { Fast growing } \\
\text { sector }\end{array}$ \\
\hline rik < ri & $\begin{array}{l}\text { Advanced and } \\
\text { slow growing } \\
\text { sector }\end{array}$ & $\begin{array}{l}\text { The sector is } \\
\text { relatively } \\
\text { lagging behind }\end{array}$ \\
\hline
\end{tabular}

again, the aftereffects of the examination with LQ = 2.92 likewise show that the creation delivered can address homegrown issues as well as be traded abroad, and furthermore the higher its similar favorable position. Notwithstanding, the inquiry for the legislature is that so far the administration has consistently done huge scope imports of rice, garlic, etc. Is it genuine that we need rice, garlic, etc, on the grounds that from the count that our horticultural, ranger service and fishery products are still in abundance of the requirements of the homegrown network, at that point for what reason do we import. Then again, we as a horticultural nation that ought to give food to the world are really doing imports.

Utilizing the Dynamic Area Remainder (DLQ) investigation strategy shows that the estimation of DLQ $=15.34$ implies that the farming, ranger service and fisheries areas as one of the parts that add to the GRDP of Ngawi Regime are becoming quicker than a similar division inside the extent of East Java Territory.

From the correlation between the estimation of the LQ and DLQ results, it shows that the rural, ranger service and fisheries areas as one of the financial segments that add to the GRDP of Ngawi region are delegated driving divisions, implying that the agrarian, ranger service and fisheries parts are as of now and later on. come to remain the base or potential (where LQ and DLQ> 1).

By utilizing the Klassen typology investigation technique the estimation of rik $=0.02$ was gotten; and ri $=2.77$ implies that the development pace of the creation estimation of the rural, ranger service and fisheries areas on the GRDP of Ngawi Regime, East Java Region, Indonesia is lower than the development pace of the horticulture, ranger service and domesticated animals parts to the GRDP of East Java Region. Furthermore, the yik esteem $=0.34$; and yi $=$ 0.13 shows that the commitment of the agrarian, ranger service and fisheries segments to the GRDP of Ngawi Regime, East Java Region, Indonesia is more noteworthy than the commitment of the farming, ranger service and fisheries divisions to the GRDP of East Java Region. From the aftereffects of the investigation (rik <ri and yik> yi), it shows that the horticulture, ranger service and fisheries parts are progressed and moderate developing segments.

From the results of the analysis using the LQ, DLQ, comparison between LQ and DLQ and Klassen Typology analysis, it shows that the agriculture, 
forestry and fisheries sectors are sustainable, meaning that the agricultural, forestry and fisheries sectors are the base / potential sectors at present and will continue to be a base / potential sector in the future even though the growth is slow. This shows that Indonesia does have potential in agriculture / agribusiness which must be managed optimally so that its people are prosperous and can provide food to the world. On the other hand, the contribution of the agricultural, forestry and fisheries sectors to the GRDP of Ngawi Regency, East Java, Indonesia is the largest of the 17 existing sectors. The agriculture, forestry and fisheries sectors have slow growth due to the government's lack of attention to these sectors. This is evident from the fact that the agriculture, forestry and fisheries sectors are the potential of the Indonesian nation to become the preferred sector not the main sector in development. This sector has also suffered a lot of damage, the conversion of fertile agricultural land to the nonagricultural sector, and so on.

For the welfare of the Indonesian people, there is only one way, namely to restore the optimal management of the potential of Natural Resources (Forestry, Plantation, Animal Husbandry, Fisheries and Food Plants), because that is the potential of the Indonesian nation as a gift from God that cannot be replaced by other sectors until the end. . Indonesia must become an agricultural country supported by the agricultural industry. Agricultural industrialization strategy in the form of agribusiness development. The basic idea of this strategy is that agribusiness development as a form of agricultural industrialization is a continuation of previous agricultural development with an orientation of increasing productivity and added value and competitiveness. The most appropriate way to develop the national economy is to develop economic activities that are the foundation of the economic life of the majority of the people and are able to accommodate the existing human resource conditions. A wise industrialization strategy is a strategy capable of realizing consistency between micro and macro performance. And a country will be able to take advantage of economic opportunities in the international market, especially in the era of free trade if the country concerned is able to produce the products needed in the international market and has a domestic resource base.

Past economic development experiences show that the agribusiness sector has made a major contribution to the national economy. The classic role of the agribusiness sector in the national economy is the provision of foodstuffs for Indonesia's population, which currently numbers \pm 226 million people. The provision of food here involves broad dimensions such as quantity, type and quality, space (distribution) and time (every day throughout the year). The role of the agriculture, forestry and fisheries sectors as a relatively inexpensive food supply has made the cost of living in Indonesia to be classified as low in the world. The relatively low cost of living in Indonesia has become one of the competitiveness of the national economy. Then with the provision of sufficient and stable foodstuffs played by the agriculture, forestry and fisheries sectors, it has contributed greatly to economic and socio-political stability, thus contributing to the creation of a climate conducive to development in all fields.

In providing employment opportunities in Indonesia, the agriculture, forestry and fisheries sectors have a very large and largest contribution among the existing sectors. With a workforce of 98 million people, around $45 \%$ is absorbed by the primary agricultural sub-sector. If the total workforce in the agribusiness sub-sector, both upstream, downstream and supporting, is taken into account, then at least $65 \%$ of the total national workforce is absorbed by the agribusiness sector. With an average number of family members of 4 people, it is estimated that $70 \%$ of Indonesia's population depends on the economic life of the agriculture, forestry and fisheries sectors.

The role of the agriculture, forestry and fisheries sectors in national exports is also quite large and their share is increasing. The large contribution of the agricultural, forestry and fisheries sectors to the total value of national exports shows that the agricultural, forestry and fisheries sectors are still the mainstay of state foreign exchange earnings to date, but they have not been optimally pursued. The increasing share of agriculture, forestry and fisheries exports indicates that this sector is able to surpass the growth of other economic sectors in contributing to exports.

The agriculture, forestry and fisheries sectors that support most of the Indonesian people, coupled with their large contribution to exports, show that the agriculture, forestry and fisheries sectors are the biggest contributors to economic growth which has been growing at an average of 7.0 percent per year.

In the future, Indonesia's agriculture, forestry and fisheries sectors still have broad development prospects and sufficient market support This potential is additionally upheld by research (Bogoviz 2019); (Joshua 2017); (Barbier 1987). Building a country by using its potential will give advantages to the nation, since (1) the assets are as of now accessible (both common assets and HR); (2) doesn't need huge capital; (3) ready to contend with different nations; (4) items delivered are better than items created in different nations; (5) diminishing the joblessness rate; (6) the network is destined to be prosperous. The Indonesian Government's help for the horticultural area is still generally high, this is indicated that the entirety of the PSE, CSE, and GSSE values shows the absolute help to the agrarian segment (TSE). Generally, the estimation of TSE expanded from Rp4.4 trillion of every $1995-1997$ to Rp330.7 trillion out of 20122014. In 2014 the estimation of TSE came to IDR 406.3 trillion. The fundamental part of the TSE is moves from buyers. This shows because of value 
security approaches for ranchers, purchasers need to follow through on product costs a lot higher than costs at the outskirt (Sudaryanto et al. 2018), yet separated from Government uphold, the utilization of innovation is expected to help the rural area to be maintainable. is the use of GIS or Topographical Data Framework (Quin 2019); (Mohammed, Majid, and Yamusa 2019); (Rahaman 2016); (Arham 2019) which can improve local exactness. The utilization of nano for food items which obviously originates from horticulture, exceptional nanotechnology in the food business in food handling, bundling, security and quality control. Nanotechnology can adjust the penetrability of bundling materials, improve boundary properties, increment mechanical and heat opposition, create surface-dynamic antimicrobials, and make nanobiodegradable bundling materials (Arham 2019) (Berekaa 2015).

The depiction above shows that the farming, ranger service and fisheries divisions are practical and have brilliant monetary possibilities later on and will never be supplanted by different parts until the end since it is a blessing from God. With such a possibility, on the off chance that it is overseen and grown all the more truly, ideally the farming, ranger service and fisheries areas will have the option to be depended on to unravel vital issues of public monetary turn of events, as in agribusiness, fisheries and ranger service can turn into the premise of financial development, given that the business records. those that are fabricated keep on taking farming, ranger service and fishery crude materials, so they can become industrialization dependent on agribusiness, fisheries and ranger service.

\section{CONCLUSION}

1. The farming, ranger service and domesticated animals part as one of the financial entertainers that adds to the gross territorial homegrown result of Ngawi Rule, East Java Indonesia, is a maintainable segment which implies that it is right now a base/expected area and will keep on being a base/possible segment later on. despite the fact that the development is moderate.

2. For the government assistance of the Indonesian public, there is no other path with the exception of "to reestablish the nation's administration to its common asset possibilities (ranger service, ranches, domesticated animals, fisheries and food crops) as a blessing from God.

3. The executives of horticulture, ranger service and fisheries is likewise upheld by innovation so it tends to be overseen mechanically by taking farming, ranger service and fisheries as crude materials.

\section{REFERENCES}

Arham, Ihsan. 2019. "Perencanaan Pembangunan Desa Pertanian Berkelanjutan Berbasis Citra Drone (Studi Kasus Desa Sukadamai Kabupaten Bogor) Ihsan Arham." (April).

Babaev, Bronislav D, Elena E Nikolaeva, and Dmitry B Babaev. 2019. "The Economic Development Potential of the Country with a Look to the Future." Proceedings of the 2nd International Conference on Economy, Management and Entrepreneurship (ICOEME 2019).

Barbier, Edward B. 1987. "The Concept of Sustainable Economic Development." Environmental Conservation 14(2): 101-10.

Bogoviz, Aleksei. 2019. "Transforming the Agricultural Sector for Better Sustainable Development: Perspectives from Russia as a Member State of the Eurasian Economic Union." IOP Conference Series: Earth and Environmental Science 274(1): 0-5.

Budiharsono, S. 2001. Teknik Analisis Pembangunan Wilayah Pesisir Dan Lautan. Pradnya Paramita.

Cahyono, S Andy and Wijaya, Wahyu Wisnu. 2014. "Pendapatan Antar Kabupaten Di Sub DAS Bengawan Solo Hulu ( Identification of the Leading Economic Sectors and Income Disparity among Regencies in Upper Bengawan Solo Sub Watershed ).” Jurnal Penelitian Sosial dan Ekonomi Kehutanan 11(1): 32-43.

Huda, Miftakhul; Santoso, Eko budi. 2014. "Pengembangan Daya Saing Daerah Kabupaten / Kota Di Propinsi Jawa Timur." Jurnal teknik pomits 3(2): 81-86.

Joshua, John. 2017. II China's Economic Growth: Towards Sustainable Economic Development and Social Justice: Volume II: The Impact of Economic Policies on the Quality of Life China's Economic Growth: Towards Sustainable Economic Development and Social Justice: Volume II: The Impact of Economic Policies on the Quality of Life.

Mohammed, Habiba I., Z. Majid, and Yamusa B. Yamusa. 2019. "GIS Based Sanitary Landfill Suitability Analysis for Sustainable Solid Waste Disposal." IOP Conference Series: Earth and Environmental Science 220(1).

Nazipati. 2007. “Aplikasi Model Static Dan Dynamic Location Quotients Dan Shift-Share Dalam Perencanaan Ekonomi Regional (Studi Kasus Kabupaten Ogan Komering Ulu Propinsi Sumatera Selatan).” EKO-REGIONAL 2.

Nong, Duy. 2019. "Potential Economic Impacts of Global Wild Catch Fishery Decline in Southeast Asia and South America." Economic Analysis and Policy 62: 213-26.

Nugrahini, Wisnujati et al. 2019. "Effort toward the Sustainable Agricultural Development within 
the Territory the ASEAN." International Journal of Engineering and Advanced Technology.

Patiung, Markus. 2018. "Penyusunan Masterplan Pengembangan Kawasan Agropolitan Kabupaten Probolinggo Tahun 2017 Markus.” Jurnal Sosio Agribisnis 18.

Quin, Emparan. 2019. "Role of Phycoremediation for Nutrients Removal." Applied Ecology \& Environmental Research 17(1): 1247-60.

Rahaman, S.Abdul. 2016. "Gis Based Multi-Criteria Decision Analysis of Bio-Physiochemical Parameters for Agricultural Land Suitability Evaluation in Kallar Watershed, Part of Bhavani Basin, Tamil Nadu." (April).
Suyatno, Suyatno. 2007. "Analisa Economic Base Terhadap Pertumbuhan Ekonomi Daerah Tingkat Ii Wonogiri : Menghadapiimplementasi Uu No. 22/1999 Dan Uu No. 5/1999." Jurnal Ekonomi Pembangunan: Kajian Masalah Ekonomi dan Pembangunan 1(2): 144.

Szirmai, Adam. 2012. "Industrialisation as an Engine of Growth in Developing Countries, 19502005." Structural Change and Economic Dynamics 23(4): 406-20. 
This page is intentionally left blank 